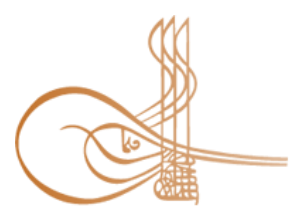

www.turkishstudies.net/economy
Turkish Studies - Economics, Finance, Politics

eISSN: $2667-5625$

Research Article / Araştırma Makalesi

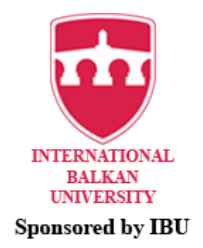

Sponsored by IBU

\title{
Hisse Senedi Piyasası Gelişimi Ekonomik Büyüme Sürecinde Bir Rol Oynar mı? BRICS-T Ülkeleri Örneği
}

\author{
Does Stock Market Development Play a Role in the Economic Growth Process? Case of BRICS-T \\ Countries
}

\author{
Günay Özcan* - Cansu Güven**
}

\begin{abstract}
Examining the interaction between the stock market and the real sector is a critical issue in terms of providing financial markets the driving force in economic growth through various channels. In the process following the increase of regional integrations on a global scale and then the liberalization of financial movements, the relationship between financial markets and economic growth has attracted attention, and research on the relationship between these two sizes has intensified, especially in recent years. While the liberalization movements in the financial markets which also include stock markets, may positively affect the economies of the country in terms of creating funds; at the same time, it may have the potential to affect negatively, as it may open up financial crises outside the country. For this purpose, the study examines the existence of the relationship between economic growth and the improving of the stock market for the BRICST countries in the period 1995-2017. In order to examine the relations, first of all, cross-section dependence and homogeneity tests were applied. Unit root and cointegration tests which are in accordance with the results of these tests, were conducted. Finally, Common Correlated Effects (CCE) and Extended Average Group (Augmented Mean Group (AMG)) cointegration estimators were used to estimate the impact's long-term coefficient. According to the findings obtained in the study, the effect of stock market development on economic growth may differ according to the specific dynamics of the countries concerned. So as a result, positively related in Brazil, Russia and China, Turkey and South Africa in a negative related, and points out that there is no statistically significant relationship in India.
\end{abstract}

Structured Abstract: With the globalization and technological transformation process, today's information societies have emerged, where socio-economic, cultural and even political integration with other countries is dominated by other countries. This transformation inevitably has created free and rapid capital mobility; and thus the relationship between financial markets and economic growth has drawn attention in the economics literature. Economic studies on the relationship between these two dimensions have intensified especially in recent years. Basically, although liberalization in financial markets can be an important factor that leads to an

\footnotetext{
${ }^{*}$ Dr. Öğretim Üyesi, Necmettin Erbakan Üniversitesi, Siyasal Bilgiler Fakültesi, İktisat Bölümü Asst. Prof. Dr, Necmettin Erbakan University, Faculty of Political Sciences, Department of Economics ORCID 0000-0002-1950-4255 gny_akel@hotmail.com

*** Doktora Öğrencisi, Necmettin Erbakan Üniversitesi, Siyasal Bilgiler Fakültesi, İktisat Bölümü PhD Student, Necmettin Erbakan University, Faculty of Political Sciences, Department of Economics ORCID 0000-0002-7490-2184 cansu.guven.50600@gmail.com

Cite as/ Atıf: Özcan, G. \& Güven, C. (2020). Hisse senedi piyasası gelişimi ekonomik büyüme sürecinde bir rol oynar mı? BRICS-T ülkeleri örneği. Turkish Studies - Economy, 15(3), 1557-1578. https://dx.doi.org/10.47644/TurkishStudies.42942

Received/Geliş: 17 April/Nisan 2020

Accepted/Kabul: 20 September/Eylül 2020

Copyright (C) INTAC LTD, Turkey 
increase in economic growth rates through various channels, it also emerges as one of the critical issues that have the potential to adversely affect economic growth due to its openness to financial crises outside the country. Because of this study has been prepared to contribute to the determination of the relationship between the stock market and economic growth among the financial markets, which are seen to be concentrated as a research subject for economists all over the world.

The aim of this study is to determine the relationship between the development of the stock market and economic growth, which is frequently mentioned as a controversial subject in the economics literature, and to obtain results about the direction of this relationship. In this context, first of all, a conceptual framework regarding the stock market and economic growth is formed in the sub-headings of the study; Why the determination of the relationship between these two economic magnitudes is important and some studies that are considered as the main source on the subject have been examined and their results are given. Then, with the literature review, which is a summary of the studies reached on the relevant subject, it was tried to be conveyed by shaping the relationship trend in general.

The first studies in the literature within the subject; With the help of variables that have been handled as a result of examining many academic studies and findings from the studies of Bagehot (1873), Schumpeter (1912), Patrick (1966), McKinnon-Shaw (1973) to the present day, the relationship between the stock market economic growth and the short and long analyzed in the period. Our research data set has been compiled from the World Bank database (World Development Indicators and Global Financial Development). Sampling covering developed and developing countries as a group of six countries $(n=6)$ were selected: BRICS-T (Brazil, Russia, India, China, South Africa and Turkey). In these selected countries, as a time-section of 23 years, 1995-2017 ( $\mathrm{t}=23)$ was included in the panel data analysis. The variables analyzed are the relationship between stock market indicators (three variables: MC, STV, TR), inflation rates and economic growth (GDP per capita). The model established in the study is " $\mathrm{gdp}=\mathrm{f}$ (pk, hdh, hih, enf)" and analysis function is;

$$
\ln k b g_{i t}=\beta_{0}+\beta_{1 i} \ln p k_{i t}+\beta_{2 i} \ln h d h_{i t}+\beta_{3 i} \ln h i h_{i t}+\beta_{4 i} \ln e n f_{i t}+\varepsilon_{i t}
$$

In this study, which examines the relationship between economic growth by including stock market indicators and inflation in the analysis; According to the results of the Westerlund and Edgerton (2007) cointegration test, it was determined that there is a long-term cointegration relationship between the variables lnkgb, lnhih, lnhdh, lnpk and lnenf. In addition, two different estimation methods are used to determine the relationship between long-term stock market development and economic growth. These methods are Common Correlated Effects (CCE) and Augmented Mean Group (AMG) methods. The horizontal section CCA used to predict long-term relationship, taking into account the interdependence and AMG test results, stock market capitalization, this effect aspects in Brazil and Turkey have shown a positive effect on economic growth in China negative as seen. It is seen that the stock turnover variable affects the economic growth only in Russia and the effect direction is positive. In Brazil, the lnhih variables were positive and negative effects in Turkey and South Africa. Inflation in Brazil CCA and AMG test results, obtained results which have a positive effect, while in Russia and Turkey; In China and India, one of the fastest developing countries in today's world, the direction of this effect is negative. When the explanations of CCE and AMG tests with statistically significant coefficient values are interpreted, a $1 \%$ increase in market capitalization (lnpk) causes an increase of approximately $0.15 \%$ in per capita economic growth in Brazil and $0.08 \%$ in China, in Turkey, which leads to decrease, up $0.21 \%$. It is seen that a $1 \%$ increase in the share turnover rate is related to economic growth only in Russia among the BRICS-T countries and creates an increase of $0.08 \%$ in economic growth. $1 \%$ increase in the stock transaction volume in Brazil positively affects the economic growth by $0.10 \%$, on the other hand it has been found to reduce, $0.16 \%$ in Turkey and $0.06 \%$ in South Africa. Finally, looking at the relationship between inflation and economic growth; countries is seen to be with positive relationship Brazil $0.038 \%$, $0.039 \%$ Russia and Turkey $0.04 \%$. In other words, when inflation increases by $1 \%$ in Brazil, it increases the economic growth in this country by $3 \%$. In Russia and Turkey in the near relation inflation rate is seen economic growth, a positive correlation was observed. In India and China, a $1 \%$ increase in the inflation rate is in economic growth; 1 was determined that it caused a decrease in order of $0.05 \%$ and $0.01 \%$.

Finally, if we make a general evaluation according to the analysis results; It is concluded that the stock market and economic growth show a positive relationship in developed countries, while economic growth in developing countries may be unrelated or negatively related to the stock market. Such a difference in the 
direction of impact can be explained by the general economic structure and fragility in financial markets in developed and developing countries.

Keywords: Economic Growth, Financial Markets, Stock Market, Comparative Studies of Countries, Panel Data Analysis.

JEL Codes: O40, G15, G12, O570, C33.

Öz: Hisse senedi piyasası ve reel sektör arasındaki etkileşimin incelenmesi, finansal piyasaların çeşitli kanallar yoluyla ekonomik büyümeye itici güç kazandırması açısından kritik bir konu olmaktadır. Küreselleşme, bölgesel entegrasyonların artışı ve finansal hareketlerin serbestleşmesinin ardından, finansal piyasalar ile ekonomik büyüme ilişkisi dikkatleri üzerine çekmiş ve bu iki büyüklük arasındaki ilişkiye dair araştırmalar özellikle son yıllarda oldukça yoğunlaşmıştır. Hisse senedi piyasalarını da içeren finansal piyasalarda serbestleşme hareketleri, fon kaynağı yaratma açısından ülke ekonomilerini olumlu etkileyebilmekle birlikte; aynı zamanda ülke dışındaki finansal krizlere açıklık oluşturabilmesi nedeniyle olumsuz etkileme potansiyelini de barındıran önemli bir konu olarak karşımıza çıkmaktadır. Bu çalışmada BRICS-T ülkeleri için 1995-2017 dönemlerinde, ekonomik büyüme ile hisse senedi piyasasının gelişmesi arasındaki ilişki incelenmektedir. İlişkinin incelenmesi için panel veri analiz yöntemlerinden ilk olarak yatay kesit bağımlılığı ve homojenlik testleri uygulanmış olup, bu testlerin sonucuna uygun olarak birim kök ve eş bütünleşme testi yapılmıștır. Son olarak etkinin uzun dönem katsayı tahmini için Ortak İlişkili Etkiler (Common Correlated Effects (CCE)) ve Genişletilmiş Ortalama Grup (Augmented Mean Group (AMG)) eşbütünleşme tahmincileri kullanılmıştır. Çalışmada elde edilen bulgulara göre ise, hisse senedi piyasası gelişiminin ekonomik büyümeye etkisi ülke dinamiklerine göre farklılıklar gösterdiği tespit edilmiş olup; Brezilya, Rusya ve Çin'de pozitif yönlü ilişkinin varlığını gösterirken Türkiye ve Güney Afrika Cumhuriyetinde negatif, Hindistan'da da istatistiksel olarak anlamlı bir ilişkinin söz konusu olmadığı sonuçlarına ulaşılmışıtır.

Anahtar Kelimeler: Ekonomik Büyüme, Finansal Piyasalar, Hisse Senedi Piyasası, Ülkelerin Karşılaştırmalı Çalışmaları, Panel Veri Analizi.

JEL Kodları: O40, G15, G12, O570, C33.

\section{Giriş}

Küreselleşme ve teknolojik dönüşüm süreciyle birlikte ulusal sınırların üstünde, diğer toplumlar ile çeşitli sosyo-ekonomik, kültürel, hatta siyasal bütünleşmelerin hakimiyet kazandığı günümüz enformasyon toplumları oluşmaya başlamıştır. Bu toplumlarda serbest ve hızlı bir sermaye hareketliliği de kaçınılmaz olarak yer edinmiștir. Sermaye hareketlerinin gerçekleșmesini sağlayan finansal piyasalar ise hem ülkeler hem de bireyler açısından iktisadi kararların alınmasında önemli bir pay edinmektedir.

Küresel boyutta bilgiye hızlı erişim ve uluslar üstü entegrasyonların oluşumu, finansal sistemde serbestleşme hareketlerinin artışılla birlikte, sermaye hareketliliğinin de hız kazanmasına yol açmıştır. Finansal serbestleşme, ülke ekonomilerinin büyüme oranlarında artışa yol açan önemli bir etken olmakla birlikte, aynı zamanda ülke dışındaki finansal krizlere açıklık sağlaması nedeniyle de ekonomik büyümeye olumsuz etki eden faktörlerden biri olarak karşımıza çıkabilmektedir. Bu nedenle ekonomi yazınında finansal piyasa hareketleri ve ekonomiye etkilerine dair, 1900'lü yıllardan itibaren çeşitli araştırmalar yapılmış ve günümüzde bu alanda çalışmaların yoğunlaşmasına karşın bu konuda ortak bir sonuca ulaştırılamamıştır.

Finansal sistem en genel tanımıyla, fon fazlası sahiplerinden fon ihtiyacı içerisinde olanlara, çeşitli araçlar kullanılarak fon akışının gerçekleştirildiği entegre bir yapı şeklinde belirtilebilir. Finansal piyasalar içerisinde, fon akışına aracılık eden önemli finansal piyasa mekanizmalarından biri de "hisse senedi piyasası"dır. Finansal piyasalar içeresinde yer alan hisse senedi piyasalarının gelişimi ve ekonomik etkilerinden önce, finansal sistemin serbestleşmesi ve ekonomiye etkilerine 
değinmek, hisse senedi piyasasının etki ve yönünün anlaşılması açısından önemli bir yer teşkil etmektedir.

Finansal serbestleşmenin kökenleri "McKinnon-Shaw" veya "Finansal Baskı Teorisi (Financial Repression Theory)" olarak adlandırılan McKinnon (1973) ve Shaw'un (1973) çalışmalarına dayandırılmasına karşın; bu çalışmaların öncesinde 1966 yılında Patrick bu teori üzerine çalışmıştır. Patrick; "Bagehot (1873) ve Schumpeter (1912)"in çalışmalarından yola çıkarak, finansal gelişimin ekonomi üzerinde 2 temel etkisinin olabileceğini belirtmiştir: ekonomiler büyüdükçe finans piyasası derinleşerek gelişecektir ya da ikincisi tam tersi bir ilişkinin geçerli olacağ1 yani finans piyasaları geliştikçe ekonomileri büyüme yönünde etkileyecektir. Bu temel çalışmalarda tartışılmış olan finansal piyasalardaki hareketliliğin reel ekonomi üzerine etkisine dair özellikle küreselleşme ve teknolojik dönüşümün ilerlediği son dönemlerde oldukça yoğun çalışmaların yapıldığı görülmekte olup; çalışmaların sonuçlarındaysa sadece 2 değişken arasında ilişkinin var ya da yok olmasından ziyade; artık niteliksel olarak etkinin yönü de incelenmektedir (Stein, 2008: 174-175).

$\mathrm{Bu}$ anlamda ilk çalışmalardan günümüz yazınına dek konudaki tartı̧̧malar incelendiğinde; hisse senedi piyasasını da içerisinde bulunduran finans piyasalarının gelişimi ile ekonomik büyüme ilişkisini açıklayan beş farklı yaklaşım olduğu belirtilebilir. İlk olarak Walter Bagehot (1873) ve Joseph A. Schumpeter'in (1912) ortaya attı̆̆ arz yönlü hipotezdir ki bu yaklaşım, tasarruflar finansal piyasa kanalıyla ekonomiye aktarılmakta, tasarrufların değerlendirilmesi ile gelişen finansal piyasalar da ekonomiyi ivmelendirerek, büyümeyi destekleyici etki sağlanacağını öne sürer. İkinci olarak ekonomik büyümenin finansal piyasada gelişmeye sebep olacağını öne süren talep takipli teoridir. Joan Robinson'un (1952) bu teorisinde ekonomiler büyüdükçe finans piyasası derinleşerek gelişmesi yönünde bir etki yaratacağından bahsedilir. Üçüncü yaklaşım ise Lewis'in (1954) iki yönlü etkileşimin varlığını savunduğu görüşüdür ki; Lewis, Ekonomik büyüme ile güçlenecek olan finansal piyasaların, daha sonra ekonomiye ek bir ivme kazandıracak güce kavuşarak, ekonomik büyüme ile karş11ıklı etkileşime girecek, kartopu etkisiyle de ekonomik büyümeyi hızlandıracaktır. Bir diğer yaklaşım; iki büyüklük arasında herhangi bir ilişkinin olmadığını savunur. Robert Lucas (1988), Stern (1989), Singh (1997) ve Naceur ve Ghazouani (2007)'in savunduğu bu ilişkisizlik hali, finansal piyasa dâhilindeki hisse senedi piyasalarının, kapitalist ekonomilerinin güçlü temsilcilerinden biri olmasına karşın; paradoksal olarak hisse senedi piyasalarındaki genişlemenin, ekonomik büyüme üzerinde hiçbir etkisi olmadığını savunurlar. Singh bu görüşünü özellikle, Avrupa kıtasındaki gelişmiş ülkelerin gelişim tarihi araştırmalarına dayandırmaktadır. Beşinci yaklaşım, finansal gelişmeden ekonomik büyümeye doğru negatif bir ilişki olduğunu öne sürmekte olup; temelinde ise finansal gelişme ekonomik büyümeden ziyade; öncelikle harcanabilir gelirin düşüşüyle etkin talebi düşürecek, finansal piyasanın dışarıya bağımlılığını arttıracak ve nihayetinde de ekonomik büyümeyi dış etkilere karşı daha kırılgan hale taşıyacağı öne sürülmektedir (Levine ve Zervos, 1998: 537; Geyikçi, 2017: 198; Yayla vd., 2017: 186; Aydemir, 2008: 38).

$\mathrm{Bu}$ çalışma, halen ekonomi yazınında tartışmalı bir konu olarak sıkça karşılaşılan hisse senedi piyasasının gelişimi ve ekonomik büyüme arasındaki ilişkinin varlığı/yokluğu ve eğer ilişki varsa bu ilişkinin hangi yönde olduğuna dair sonuçlar elde edilmek amacıyla hazırlanmıştır. Bu bağlamda çalışmanın alt başlıklarında öncelikle, hisse senedi piyasası ile ekonomik büyümeye dair kavramsal bir çerçeve oluşturulmak üzere; bu iki ekonomik büyüklük arasındaki ilişkinin tespitinin niçin önem taşıdığı ve konuya dair yapılmış temel kaynak olarak görülen bazı çalışmalar incelenerek, sonuçlarına yer verilmiştir. Ardından ilgili konuda yapılmış ulaşabilinen çalışmaların özeti niteliğinde literatür taramasıyla, ilişkinin yönünün genel olarak nasıl bir trend içerisinde seyrettiği şekillendirilerek aktarılmaya çalışılmıştır. Veri ve yöntem alt başlığı içerisinde, araştırmaya esas olan hisse senedi piyasası gelişimi ile ekonomik büyüme ilişkisinin tespit edilmesine yönelik olarak seçilen veri setinin, zaman ve kesit boyutları ile analizde izlenecek yönteme yer verilmiştir. 
Gelişmiş ve gelişmekte olan ülke gruplarını barındıran veri setimiz BRICS-T (Brezilya, Rusya, Hindistan, Çin, Güney Afrika ve Türkiye) ülkeleri ile 1995-2017 arasında 23 yıllık dönemi kapsayan hisse senedi piyasası göstergeleri (üç değişken: MC, STV, TR), enflasyon oranları ve ekonomik büyüme göstergesi (bir değişken: kişi başı GDP) ilişkisi analiz edilerek; araştırma sonucunda elde edilen bulguların aktarılacağı çalışmamızda, hisse senedi piyasası ekonomik büyüme ilişkisinin yönüne dair hem yöntem hem de örneklem açısından literatüre katkı sağlanmas1 planlanmaktadır.

\section{Kavramsal Çerçeve}

Hisse senedi piyasası; sermayesi paylara bölünerek karşılığında kıymetli evraklar çıartılması ve bunların yasal olarak fon arz edenler ile talep edenleri arasında alınıp-satılabilmesine imkân sağlayan piyasalardır. Uzun vadeli fon arz ve talepçilerini bir araya getiren hisse senedi piyasaları, gelişmiş ülkelerde daha etkin bir şekilde çalışırken; Türkiye gibi gelişmekte olan ülkelerde etkinlik düzeyi bu seviyelerde olmamakla birlikte ülke ekonomilerinde önemli bir gösterge olarak rol almaktadır. Bunun nedeni, hisse senedi fiyatlarının belirlenmesinde ülkenin genel ekonomisini belirleyicilerinden temel makroekonomik değişkenlerle ilişkili olarak, enflasyon, kar payları, beklenen verim gibi çeşitli değişkenlerin gelişmekte olan ülkelerde oynaklığının daha yüksek olması dolayısıyla hisse senedi piyasasını daha fazla etkilemesinden kaynaklanmaktadır (Şahin ve Durmuş, 2018: 809).

Hisse senedi piyasasını içerisinde bulunduran finansal piyasalar, temel olarak ekonomilerde fon tedariği sağlayıcı bir mekanizma görevi üstlenmektedir. Hisse senedi piyasası, ekonomik büyümede rol alan temel değişkenlerden kabul (özellikle gelişmekte olan ülkelerde) edilmekte ve ekonomilerde can damarlarından biri olarak görülmektedir (Kırankabeş ve Başarır, 2012: 138; Aslan ve Küçükaksoy, 2006: 28).

Etkin işleyen bir finans sistemi, fon fazlası bulunan arz sağlayıcılarındaki düşük değerli mevduatların, ekonomiye aktarılarak büyük ve karlı yatırımlara dönüştürülebilmesi için imkân sunarken; ayrıca fonların değerlendirilmesi sürecinde piyasada risk-kar incelemeleri veya kaynak yönetimi gibi konularda geniş bilgi gerekmeksizin, tasarruf sahiplerinin elde tutarak uğrayabilecekleri kayıpları minimize ederek kar etmelerine yardımcı olmaktadır. Dolayısıyla hisse senedi piyasasının, kaynakların etkin kullanımı ve ekonomideki verimliliğin arttırılması sayesinde ekonomik büyümeyi de arttıracağı literatürde genel olarak kabul görmektedir (Hoque ve Yakob, 2017: 4; Levine ve Zervos: 1998).

Hisse senedi piyasasının gelişimi, küresel ekonomi ve finans alanında, kurumsal finansman ve iktisadi faaliyette yaptıkları etkiyi takiben gelişimsel bir rol üstlenmiştir. Örneğin borsalar likiditeleri nedeniyle firmaların ihtiyaç duydukları sermayeyi hızlı bir şekilde almalarını sağlayarak sermaye tahsisini, yatırımı ve büyümeyi kolaylaştırmaktadır. Borsalar aynı zamanda hisse senetlerinin işlem gördüğü kolaylık nedeniyle yatırım riskini azaltmaya da yardımcı olmaktadır. Dolayısıyla borsa faaliyeti çoğu ekonomide ekonomik faaliyetlerin seviyesini belirlemeye yardımc1 olarak, gelişimi desteklemede gittikçe önemli bir rol almaktadır (Adjasi ve Biekpe, 2006: 144).

Finansal gelişme ve ekonomik büyüme arasındaki ilişki üzerine özellikle son birkaç 10 yıllık dönem içerisinde etki yönünün tespit edilmesi amacıyla, ekonomi yazınında oldukça geniş çalışmaların yapıldığı görülmektedir. Günümüzde yoğunlaşmış bu tartışmalar, ilk olarak 1911'de Schumpeter'in dönemsel çalışmasına dayandırılmaktadır; bu çalışma, iyi işleyen bir finansal sistemin, teknolojik yenilikleri kaynakların verimli bir şekilde tahsis edilmesi yoluyla hızlandırarak ekonomik büyümeyi teşvik ettiğini savunmaktadır. Bu doğrultuda Gurley ve Shaw'un (1955) çalışması, iyi gelişmiş finansal piyasaların, yatırımcılara finansal kapasitelerini ve nihayetinde ekonomik büyümeye katkıda bulunan ticaretin verimliliğini artırmak için gerekli fonları sağlayarak sermaye birikimini artırabileceğini belirtmektedir. Bu argüman daha sonra Goldsmith (1959), McKinnon (1973) ve Shaw (1973) gibi bilim adamları tarafından da desteklenmiştir. Aslında, 
Goldsmith-McKinnon-Shaw'ın argümanları birçok gelişmekte olan ülkede finans sektörünün serbestleşmesinin temelini atmıştır (Nagaishi, 1999: 2004).

Levine ve Zervos (1998), borsaların bankac1lık sisteminden farkl1 türlerde finansal hizmetler sunduğunu, yatırım ve büyümeye farklı türde ivme kazandırdığını iddia etmektedir. Örneğin, piyasa kapitalizasyonu gibi borsa gelişim göstergelerinin bir ekonominin sermayeyi harekete geçirme ve riskleri daha verimli bir şekilde çeşitlendirme kabiliyetini artırabilirken, ticari değer ve ciro oranı gibi likidite önlemlerinin işlem maliyetlerini düşürdüğüne, piyasaların etkin işleyişi sağladığına inanılmaktadır (Arestis ve Demetriades, 2001; Greenwood ve Smith, 1997). Büyük borsaların tasarrufları mobilize etme maliyetini azaltabileceğini ve böylece çoğu üretken teknolojiye yatırım yapmayı kolaylaştırdığını savunmaktadırlar. Bencivenga vd. (1996) ve Levine (1991) borsa likiditesinin (hisse senedi alım satım işlemlerinin kolayca yapılabilirliğinin) büyüme için çok önemli olduğu görüşündedirler.

Sermaye piyasalarının özellikle gelişmekte olan ülkelerde kalkınmanın finansmanı için kaynak yaratma özelliğinin sıkça tartışlır hale gelmesiyle, gelişmekte olan ülkelerin çoğu 1980 'lerden bu yana borsalarını geliştirmek için politikalar uygulamaya yönelmişlerdir. Nitekim piyasa liberalizasyonu, uluslararası ticaret kanallarını açarak, yabancı yatırımlar ve sermayeyi uluslararası dolaşıma dâhil ederek, yerel fonların sermaye yaratılmasına katkısını oldukça arttıracağ beklentisi bu politikalara yön vermektedir (Hoque ve Yakob, 2017: 4).

\section{Literatür Taraması}

Ampirik literatürde hisse senedi piyasası gelişiminin ekonomik büyümeye etkisini araştıran çok sayıda araştırma mevcuttur. Fakat özellikle yirminci yüzyılın son çeyreklik döneminden sonra yoğunlaşan oldukça geniş bir literatüre ulaşılmasına karşın, yapılan çalışma sonuçlarında etkinin yönüne dair kesin ve ortak bir kanıt sunulmamıştır. Örneğin, Atje ve Jovanovic (1993), Levine ve Zervos (1998), Tuncer ve Alövsat (1998), Chang (2001), Beck ve Levine (2004), Rioja ve Valev (2004) Enisan and Olufisayo (2009), Alawin vd. (2018) gibi çalışmalar borsadaki gelişmelerin ekonomik büyümeyi arttırdığını savunurken; Singh (1997), Harris (1997), Naceur ve Ghazouani (2007), Gilchrist vd. (2009), Næs vd. (2011) ve Farmer (2012) gibi bazı çalışmalar ise borsanın gelişiminin ekonomik büyümeyle ilişkisiz ya da bazen negatif ilişkili olabileceğini ileri sürmektedirler.

Belirtildiği üzere son dönemlerde finansal piyasalar ile ekonomik büyüme ilişkisine dair geniş bir literatür bulunmakla birlikte, hisse senedi piyasası ile ekonomik büyüme ilişkisi nispeten az olmakla birlikte yoğunlaşmanın son dönemlerde arttı̆̆ söylenebilir. Hazırlanan bu çalışmada konuya dair özellikle 1996-2019 aralığında yayınlanmış birçok çalışma ve sonuçları incelenmiştir. Bu çalışmalarda hisse senedi ile ekonomik büyüme ilişkisinin incelenmesi kapsamında ekonomik büyüme değişkeni olarak kişi başı büyüme oranı (sabit 2010 US \$) verileri incelemeye dahil edilmiştir. Hisse senedi piyasası gelişim göstergeleri olarak ise daha geniş bir gösterge verisi baz alınmıştır. Bu bağlamda bazı çalışmalar borsa endeks değerleri, tasarruf oranı, para arzı, bankaların kredi kullandırmasını hisse senedi piyasası gelişim göstergesi olarak inceledikleri gibi, genel eğilim dikkate alındığında hisse senedi piyasası gelişmişliğinin belirleyicisi olarak 3 temel değişken ağırlıklı olarak incelemelerde ele alınmıştır. Bu değişkenler ise: piyasalardaki derinliği temsilen "piyasa kapitalizasyon oranı", hisse senedi piyasasındaki etkinliği temsil eden "hisse senedi devir hızı" ve hisse senedi piyasasında likiditeyi temsil eden "hisse senetlerinin işlem hacmi" olarak belirtilebilir.

Çalışmada ele alınan literatür bulguları, konudaki nihai sonuçların kümülatifini temsil edemeyecek olsa da bu çalışma kapsamında incelenen literatür bulgularının genel eğilimine gösterge olarak hazırlanmıştır. Buna göre, hisse senedi piyasası ile ekonomik büyüme ilişkisine dair araştırma sonuçlarının ilişkinin yönüne göre (pozitif ilişkili, negatif ilişkili ve ilişki yoktur) üç grupta sınıflandıracak olursak; çalışmalardan bazılarının sonuçları ve ilişkiyi inceleme yöntemleri tablolarla kısaca özetlenmiştir. 
Tablo 1: Hisse Senedi Piyasas1 -Ekonomik Büyüme İlişkisine Dair Pozitif Sonuçlu Literatür

\begin{tabular}{|c|c|c|c|c|c|}
\hline Yazar & Ülke & Dönem & Yöntem & HSP Göstergeleri & Sonuç \\
\hline $\begin{array}{l}\text { Levine ve } \\
\text { Zervos (1996) }\end{array}$ & 47 Ülke & $\begin{array}{l}1976 \\
1993 \\
\end{array}$ & Nedensellik & MC, STV, TR & $(+)$ \\
\hline Chang (2001) & 70 Ülke & $\begin{array}{l}1975 \\
1992\end{array}$ & Nedensellik & $\mathrm{MC}, \mathrm{STV}$ & $(+)$ \\
\hline $\begin{array}{l}\text { Nieuwerburgh } \\
\text { vd (2006) }\end{array}$ & Belçika & $\begin{array}{l}1830 \\
2000\end{array}$ & $\begin{array}{l}\text { Eşbütünleşme } \\
\text { GrangerNedenselli } \\
\text { k }\end{array}$ & $\begin{array}{l}\text { MC, Brussels Stock } \\
\text { Exchange Endeks Değerleri }\end{array}$ & $(+)$ \\
\hline $\begin{array}{l}\text { Adjasi and } \\
\text { Biekpe (2006) }\end{array}$ & $\begin{array}{l}14 \text { Afrika } \\
\text { Ülkesi }\end{array}$ & $\begin{array}{l}1975 \\
2011\end{array}$ & Dengesiz Panel & MC, STV, TR & $(+)$ \\
\hline $\begin{array}{l}\text { Enisan- } \\
\text { Olufisayo } \\
\text { (2009) } \\
\end{array}$ & $\begin{array}{l}\text { Sahra Altı } \\
\text { Afrika-7 } \\
\text { Ülke }\end{array}$ & $\begin{array}{l}1980 \\
2004\end{array}$ & ARDL, VECM & MC, STV & $(+)$ \\
\hline $\begin{array}{l}\text { Nowbutsing } \\
\text { vd (2009) }\end{array}$ & Mauritius & $\begin{array}{l}1989 \\
2006 \\
\end{array}$ & ECM & MC, STV & $(+)$ \\
\hline $\begin{array}{l}\text { Antonios } \\
(2010)\end{array}$ & Almanya & $\begin{array}{l}1965 \\
2007\end{array}$ & VECM & SMI (index) & $(+)$ \\
\hline İshioro (2013) & Zimbabwe & $\begin{array}{l}1990 \\
2010\end{array}$ & $\begin{array}{l}\text { Toda and } \\
\text { Yamamoto }\end{array}$ & MC, STV & $(+)$ \\
\hline $\begin{array}{l}\text { Jahfer vd } \\
(2014)\end{array}$ & Sri Lanka & $\begin{array}{l}1996 \\
2011 \\
\end{array}$ & VECM & MC, STV & $(+)$ \\
\hline $\begin{array}{l}\text { Naik ve Padhi } \\
\text { (2015) }\end{array}$ & $\begin{array}{l}\text { 27Yüksele } \\
\text { n Ekonomi }\end{array}$ & $\begin{array}{l}1995 \\
2012\end{array}$ & Nedensellik & $\mathrm{MC}, \mathrm{STV}, \mathrm{TR}$ & $(+)$ \\
\hline $\begin{array}{l}\text { Lazarov vd } \\
(2016)\end{array}$ & $\begin{array}{l}\text { Makedony } \\
\text { a }\end{array}$ & $\begin{array}{l}2002 \\
2012 \\
\end{array}$ & GMM & $\mathrm{MC}$ & $(+)$ \\
\hline $\begin{array}{l}\text { Azam vd } \\
(2016)\end{array}$ & Asya-4 & $\begin{array}{l}1991 \\
2012\end{array}$ & ARDL & $\mathrm{MC}$ & $(+)$ \\
\hline $\begin{array}{l}\text { Nyasha, } \\
\text { Odhiambo } \\
\text { (2016) }\end{array}$ & Kenya & $\begin{array}{l}1980 \\
2012\end{array}$ & ARDL & MC, STV, TR & $(+)$ \\
\hline $\begin{array}{l}\text { Pan ve Mishra } \\
(2016)\end{array}$ & Çin & $\begin{array}{l}\text { 1991:12 } \\
015: 11 \\
\end{array}$ & ARDL & $\mathrm{MC}$ & \\
\hline $\begin{array}{l}\text { Hoque ve } \\
\text { Yakob (2017) }\end{array}$ & Malezya & $\begin{array}{l}1981 \\
2016\end{array}$ & ARDL & $\mathrm{MC}$ & $(+)$ \\
\hline Ho (2018) & $\begin{array}{l}\text { Hong } \\
\text { Kong }\end{array}$ & $\begin{array}{l}\text { 1986:q2 } \\
\text { 2015:q4 } \\
\end{array}$ & ARDL & MC, STV, TR & $(+)$ \\
\hline $\begin{array}{l}\text { Alawin, Ali ve } \\
\text { Merza (2018) }\end{array}$ & $\begin{array}{l}\text { Bir.Ar. } \\
\text { Em. ve } \\
\text { Nijerya }\end{array}$ & $\begin{array}{l}2004 \\
2015\end{array}$ & Nedensellik & MC, STV, TR & $(+)$ \\
\hline $\begin{array}{l}\text { Tekin ve } \\
\text { Yener (2019) }\end{array}$ & $\begin{array}{l}\text { BRICS-G7 } \\
\text { ve Türkiye } \\
\text { (13 Ülke) }\end{array}$ & $\begin{array}{l}\text { 1998:q1 } \\
\text { 2016:q4 }\end{array}$ & $\begin{array}{l}\text { Johansen } \\
\text { Eşbütünleşme } \\
\text { Granger } \\
\text { Nedensellik } \\
\end{array}$ & $\begin{array}{l}\text { Hisse Senedi Endeks } \\
\text { Değerleri }\end{array}$ & $\begin{array}{l}(+) \\
(\mathrm{ABD} \\
\text { Hariç) }\end{array}$ \\
\hline Helhel (2019) & $\begin{array}{l}\text { Kurılgan } \\
\text { Beşli }\end{array}$ & $\begin{array}{l}2002 \\
2016 \\
\end{array}$ & $\begin{array}{l}\text { Panel DOLS ve } \\
\text { FMOLS Testi }\end{array}$ & MC, STV, TR & $(+)$ \\
\hline $\begin{array}{l}\text { Kar ve Ağır } \\
\text { (2011) }\end{array}$ & Türkiye & $\begin{array}{l}\text { 1987:q1 } \\
\text { 2002:q2 }\end{array}$ & Eşbütünleşme & MC, STV, TR & $(+)$ \\
\hline Yücel (2009) & Türkiye & $\begin{array}{l}1997: 1 \\
2007: 8 \\
\end{array}$ & $\begin{array}{l}\text { JJ- Temel } \\
\text { Bileşenler Analizi }\end{array}$ & İMKB tüm endeks verileri & $(+)$ \\
\hline $\begin{array}{l}\text { Kırankabeş, } \\
\text { Başarır (2012) }\end{array}$ & Türkiye & $\begin{array}{c}1998: 1 \\
2010: 12\end{array}$ & $\begin{array}{l}\text { Granger } \\
\text { nedensellik }\end{array}$ & ISE 100 endeks verileri & $(+)$ \\
\hline
\end{tabular}




\begin{tabular}{|c|c|c|c|c|c|}
\hline $\begin{array}{l}\text { Bayar vd } \\
(2014)\end{array}$ & Türkiye & $\begin{array}{l}1999 \\
2013 \\
\end{array}$ & $\begin{array}{l}\text { JJ eşbütünlşme } \\
\text { Granger causality }\end{array}$ & MC, STV, TR & $(+)$ \\
\hline $\begin{array}{l}\text { Geyikçi } \\
\text { (2017) }\end{array}$ & Türkiye & $\begin{array}{l}1986- \\
2016\end{array}$ & ARDL & $\mathrm{MC}$ & $(+)$ \\
\hline $\begin{array}{l}\text { Yayla vd } \\
\text { (2017) }\end{array}$ & Türkiye & $\begin{array}{c}2006: 1 \\
2016: 10\end{array}$ & ARDL & BIST100 & $(+)$ \\
\hline $\begin{array}{l}\text { Şahin ve } \\
\text { Durmuş } \\
(2018)\end{array}$ & Türkiye & $\begin{array}{c}2005: 1 \\
2017: 12\end{array}$ & Toda-Yamamoto & BIST-100 & $(+)$ \\
\hline $\begin{array}{l}\text { Çetenak ve } \\
\text { Haykır (2019) }\end{array}$ & Türkiye & $\begin{array}{l}\text { 1995:q1 } \\
\text { 2018:q1 }\end{array}$ & $\begin{array}{l}\text { Granger } \\
\text { nedensellik }\end{array}$ & BIST-100 & $(+)$ \\
\hline $\begin{array}{l}\text { Akyol ve } \\
\text { Karakuş(2019) }\end{array}$ & Türkiye & $\begin{array}{l}2007 q 6 \\
2019 q 6\end{array}$ & $\begin{array}{l}\text { Engle-Granger } \\
\text { DOLS ve FMOLS } \\
\text { Toda-Yamamoto }\end{array}$ & $\begin{array}{l}\text { Sanayi Üretim Endeksive } \\
\text { BİST } 100\end{array}$ & $(+)$ \\
\hline
\end{tabular}

Hisse senedi piyasası ve ekonomik büyüme ilișkisi dahilinde Avrupa'nın başlıca gelişmiș ülkelerinde (Almanya, Belçika, Fransa, Portekiz, Hollanda ve Birleşik Krallık gibi) hisse senedi piyasası gelişiminin ekonomik büyümeye etkisini araştıran çalışmalarda ekonomik büyümeye doğru güçlü bir nedensellik tespit edildiği ortaya çıkmaktadır (Chang (2001); Nieuwerburgh vd. (2006); Antonios (2010); Boubakari ve Jin (2010); Tekin ve Yener (2019); Naik ve Padhi (2015) ). Afrika ülkeleri için yapılan çalışmalar ise kısa dönemde de olumlu bir ilişki göstermesine karşın, uzun dönemde ve özellikle orta-yüksek gelir grubundaki ülkelerde hisse senedi piyasası gelişiminin ekonomik büyüme ile güçlü bir ilişkisi olduğu ortaya çıkmaktadır (Adjasi ve Biekpe (2006); Nowbutsing ve Odit (2009); Enisan ve Olufisayo (2009) ). Türkiye özelinde yapılan çalışmalardaysa, uzun dönemli nedensellik ilişkisi yoğunluklu olmakla birlikte (Kar ve Ağır (2011); Yücel (2009); Kırankabeş ve Başarır (2012); Bayar vd (2014); Geyikçi (2017); Yayla vd (2017); Çetenak ve Haykır (2019) ); son birkaç yılda çift yönlü nedensellik ilişkisi tespit eden (Şahin ve Durmuş (2018); Akyol ve Karakuş (2019) ) çalışmalar da bulunmaktadır. 
Tablo 2: Hisse Senedi Piyasası -Ekonomik Büyüme İlişkisine Dair Negatif ve İlişkisizlik Literatürü

\begin{tabular}{|c|c|c|c|c|c|}
\hline Yazar & Ülke & Dönem & Yöntem & $\begin{array}{c}\text { HSP } \\
\text { Göstergeler } \\
\text { i }\end{array}$ & Sonuç \\
\hline $\begin{array}{l}\text { Levine ve } \\
\text { Zervos (1998) }\end{array}$ & 47 Ülke & $\begin{array}{l}1976 \\
1993\end{array}$ & $\begin{array}{l}\text { Ülkeler } \\
\text { Arası } \\
\text { Analiz }\end{array}$ & $\begin{array}{l}\text { MC, STV, } \\
\text { TR, Saving, } \\
\text { Bank credits }\end{array}$ & $\begin{array}{l}\text { Finansal piyasalar, büyüme için } \\
\text { önemli hizmetler sağlar } \\
\text { Ancak Hisse senedi piyasası } \\
\text { oynaklığı ve uluslararas } 1 \\
\text { entegrasyonun büyüme ile güçlü } \\
\text { bir bağlantısı yoktur }\end{array}$ \\
\hline $\begin{array}{l}\text { Tuncer ve } \\
\text { Alövsat } \\
(1998)\end{array}$ & 20 ülke & $\begin{array}{l}1981 \\
1994\end{array}$ & $\begin{array}{l}\text { Granger } \\
\text { Nedensellik } \\
\text { Sims Testi }\end{array}$ & $\mathrm{MC}$ & $\begin{array}{ll}\text { Ülke bazında } & \text { ilişki } \\
\text { bulanamamışken; } & \\
\text { Borsa ile ekonomik } & \text { büyüme } \\
\text { ilişkisi güçlüdür } & \end{array}$ \\
\hline $\begin{array}{l}\text { Arestis, } \\
\text { Demetriades } \\
\text { ve Luintel } \\
(2001)\end{array}$ & $\begin{array}{l}\text { Gelişmiş } \\
\text { Ülkeler } \\
\text { Grubunda } \\
\text { n } 5 \text { Ülke }\end{array}$ & $\begin{array}{l}1973 \\
1998\end{array}$ & $\begin{array}{l}\text { Panel } \\
\text { Eşbütünleş } \\
\text { me }\end{array}$ & SMC, SMV & $\begin{array}{l}\text { Hisse senedi oynaklığı ile } \\
\text { ekonomik büyümeyi negatif } \\
\text { etkiler }\end{array}$ \\
\hline $\begin{array}{l}\text { Gökdeniz, } \\
\text { Erdoğan, } \\
\text { Kalyüncü(200 } \\
\text { 3) }\end{array}$ & Türkiye & $\begin{array}{l}1989 \\
2002\end{array}$ & $\begin{array}{l}\text { En küçük } \\
\text { kareler } \\
\text { Yöntemi }\end{array}$ & ENF, M2 & $\begin{array}{l}\text { Türkiye için ekonomik büyüme } \\
\text { ile hisse senedi piyasası ilişkisiz }\end{array}$ \\
\hline $\begin{array}{l}\text { Naceur ve } \\
\text { Ghazouani } \\
(2007)\end{array}$ & $\begin{array}{l}11 \text { adet } \\
\text { MENA } \\
\text { ülkeleri }\end{array}$ & $\begin{array}{l}1979- \\
2003\end{array}$ & $\begin{array}{l}\text { GMM } \\
\text { dinamik } \\
\text { panel }\end{array}$ & $\begin{array}{l}\text { MC, STV, } \\
\text { TR }\end{array}$ & $\begin{array}{l}\text { Hisse senedi piyasası ekonomik } \\
\text { büyüme ilişkisi yoktur }\end{array}$ \\
\hline $\begin{array}{l}\text { Boubakari ve } \\
\text { Jin }(2010)\end{array}$ & $\begin{array}{l}5 \text { Euronext } \\
\text { ülke }\end{array}$ & $\begin{array}{l}1995: q \\
1 \\
2008: q \\
4\end{array}$ & $\begin{array}{l}\text { Granger } \\
\text { Nedensellik }\end{array}$ & $\begin{array}{l}\text { MC, STV, } \\
\text { TR }\end{array}$ & $\begin{array}{l}\text { Gelişmiş ülke hisse senedi } \\
\text { piyasası ile ekonomik büyümesi } \\
\text { ilişskilidir. } \\
\text { Buna karşın hisse senedi piyasası } \\
\text { küçük ve likiditesi düşük olan } \\
\text { ülkelerde ilişki yoktur }\end{array}$ \\
\hline $\begin{array}{l}\text { Gözbaşı } \\
(2015)\end{array}$ & $\begin{array}{l}\text { Gelişmekt } \\
\text { e Olan } 7 \\
\text { Ülke }\end{array}$ & $\begin{array}{l}1989- \\
2011\end{array}$ & $\begin{array}{l}\text { Eşbütünleş } \\
\text { me } \\
\text { Nedensellik }\end{array}$ & $\mathrm{MC}, \mathrm{TR}$ & $\begin{array}{l}\text { Uzun Dönem İlişki Yok } \\
\text { Ancak Nedensellik İlişkisi Var }\end{array}$ \\
\hline $\begin{array}{l}\text { Pan ve Mishra } \\
\text { (2017) }\end{array}$ & Çin & $\begin{array}{l}2007- \\
2012\end{array}$ & ARDL & $\mathrm{MC}$ & $\begin{array}{l}\text { Uzun dönemde negatif ilişki } \\
\text { Kısa dönemde ise ilișki yok }\end{array}$ \\
\hline \multicolumn{4}{|c|}{$\begin{array}{l}\text { MC : Market capitalization } \rightarrow \text { Piyasa kapitalizasyonu } \\
\text { STV:Total value of stocks traded as a percent of GDP } \\
\rightarrow \text { İslemHacmi } \\
\text { TR : Turnover ratio of stocks traded (total value of stocks } \\
\text { traded/market capitalization) } \rightarrow \text { Devir hızı }\end{array}$} & \multicolumn{2}{|c|}{$\begin{array}{l}\text { SMV : Hisse senedi piyasa oynaklığı (Stock Market } \\
\text { Volatility) } \\
\text { ENF : Enflasyon Oranı } \\
\text { M2 : Parasal Büyüklük }\end{array}$} \\
\hline
\end{tabular}

Hisse senedi piyasasından ekonomik büyümeye doğru pozitif yönlü bir ilişkinin olduğuna ulaşan çalışmalar literatürde büyük çoğunlukta olmakla birlikte; hisse senedi piyasası ile ekonomik büyüme arasında herhangi bir ilişki tespit edemeyen veya hisse senedi piyasasının ekonomik büyüme üzerinde olumsuz etkisini tespit eden çalışmalara da rastlanmaktadır. Singh (1997) çalışmasında hisse senedi piyasalarının, günümüzde kapitalist ekonomilerinin güçlü temsilcilerinden biri olmasına karşın; paradoksal olarak hisse senedi piyasalarındaki genişlemenin, ekonomik büyüme üzerinde etkili olmayacağını savunur. Bu görüşünü ise, Avrupa kıtasındaki gelişmiş ülkelerin gelişim tarihi araştırmalarına dayandırarak, ortaya koymaktadır (Singh, 1997: 780). Arestis vd. (2001), gelişmiş ülkeler grubundan seçilmiş 5 ülkeli çalışmalarında banka sektöründeki gelişme ile ekonomik büyüme ilişkisinin önemini işaret etmekle birlikte; hisse senedi piyasası etkisine dair kesin bir ilişki yönü ortaya koyulamadığını öne sürmektedirler. Bunlara ilaveten çalışmalarında hisse senedi piyasası volatilitesinin de ekonomik büyüme üzerinde olumsuz etkileri olduğu savunulmaktadır. 
Tablolarda özetlenmiş olan hisse senedi piyasası gelişimi ile ekonomik gelişme arasındaki ilişkinin yönüne dair son dönemlerde yapılmış akademik çalışmalar incelenmiştir. Bu çalışmalardan elde edilen literatür bulgularına dayanılarak; hisse senedi piyasası gelişimi ile ekonomik gelişme arasındaki ilişkinin yönüne dair genel kabule ulaşmış bir teori bulunmadığı belirtilebilmektedir. Bu duruma temel teşkil eden unsurlar arasında; ülkelerin ekonomik yapıları, kurumsal örgütlenme yapısı, ekonomik kalkınma seviyesi veya çalışmalarda incelenen zaman ve ülke boyutu farklılıkları gibi çeşitli dinamiklerinden kaynaklanan birçok sebep gösterilebilir. Ancak, ekonomik büyüme ile hisse senedi piyasası gelişiminin pozitif yönlü olduğuna dair araştırma bulguları ağırlıktadır. Yani incelenen çalışmaların büyük çoğunluğu, yapmış olduğu analizler sonucu iki ekonomik büyüklük arasında pozitif ilişkinin olduğunu ortaya koymaktadır. Seçilmiş literatürden incelenen çalışmaların az bir kısmı ise iki değişken arasında ilişkinin negatif yönlü olduğunu ya da ilişkinin olmadığını göstermektedir.

\section{Veri ve Model}

Çalışmada 1995-2017 dönemine ait yıllık veriler kullanılarak BRICS-T ülkeleri (Brezilya, Rusya, Hindistan, Çin, Güney Afrika ve Türkiye) üzerinde hisse senedi piyasasının gelişimi ve ekonomik büyüme ilişkisi incelenmiştir. Analizde kullanılacak değişkenler belirlenirken literatürde hisse senedi piyasasını temsilen yoğunluklu kullanılan değişkenler dikkate alınmıştır. Hisse senedi piyasası gelişimi göstergesi olarak üç değişken seçilmiştir. Bunlar; piyasalarda derinliğini temsil eden "pk- piyasa kapitalizasyonunun GSYIHH'ya oranı", etkinliği temsil eden "hdh- hisse senedi piyasası devir hızı (işlem hacmi/toplam piyasa değeri)" ve üçüncü olarak da "hih-hisse senedi piyasası işlem hacmi” verileri kullanılmıştır.

Tablo 3: Değişkenlerin Açıklaması

\begin{tabular}{lllc}
\hline Değişken Simgesi & \multicolumn{1}{c}{ Açıklama } & Kaynak & Dönem \\
\hline lnkbg & Kişi başına milli gelir & Dünya Bankası (WDI) & $1995-2017$ \\
lnpk & Piyasa kapitalizasyon oranı & Dünya Bankası (GFD) & $1995-2017$ \\
lnhdh & Hisse senedi piyasası devir hızı & Dünya Bankası (GFD) & $1995-2017$ \\
lnhih & Hisse senedi piyasası işlem hacmi & Dünya Bankası (GFD) & $1995-2017$ \\
lnenf & Enflasyon oranı & Dünya Bankası (WDI) & $1995-2017$ \\
\hline WDI :World Development Indicators & & \\
GFD :Global Financial Development & & \\
\hline
\end{tabular}

Çalışmada test edilen model aşağıdaki gibidir;

$g d p=f(p k, h d h$, hih, enf)

Model değişkenlerin logaritması alınarak analiz edilmiştir. Eşitlik 1'de yer alan fonksiyona $\beta_{0}$ ve $\varepsilon_{i t}$ hata teriminin olduğu açık şekli aşağıdaki gibidir;

$$
\ln k b g_{i t}=\beta_{0}+\beta_{1 i} \ln p k_{i t}+\beta_{2 i} \ln h d h_{i t}+\beta_{3 i} \ln h i h_{i t}+\beta_{4 i} \ln e n f_{i t}+\varepsilon_{i t}
$$

Burada $\mathrm{i}=1, \ldots, \mathrm{N}$ panelde yer alan her bir ülkeyi; $\mathrm{t}=1, \ldots, \mathrm{T}$ ise zaman kesitini göstermektedir.

\section{Yöntem ve Bulgular}

Çalışmada analiz için ilk olarak yatay kesit bağımlılığı ve homojenite testleri uygulanmıştır. Yatay kesit bağımlılığının test edilmesinin amacı, gittikçe birbirine entegre olan dünyada, ülkelere ait serilerin yatay kesit bağımlılığının olup olmadığının ortaya konulmasıdır. Çünkü ülkeler arasında etkileşim oldukça yüksektir ve bu nedenle bir ülke ekonomisinde meydana gelen şoklardan, diğer ülkelerin de etkilenmesi muhtemeldir. Seriler arasında yatay kesit bağımlılığ 1 tespit edilmesine karşın, bu durum göz ardı edilirse; elde edilen bulgular da önemli ölçüde etkilenecektir (Breusch ve 
Pagan, 1980). Sonraki adımlarda yapılacak analizler yatay kesit bağımlılığını dikkate alan testlerin uygulanmasiyla devam edilir.

Çalışmada serilerde ve modelde yatay kesit bağımlılı̆̆ını incelemek için Breusch ve Pagan (1980) tarafından geliştirilen LM testi ve Pesaran (2004)'in geliştirdiği CD testleri uygulanmıştır. $\mathrm{LM}$ ve $\mathrm{CD}$ testlerinin birbirlerinden farkları, zaman $(\mathrm{T})$ ve kesit $(\mathrm{N})$ boyutlarından kaynaklanmaktadır. T $>\mathrm{N}$ durumunda Breusch ve Pagan (1980) LM testi, N/T'nin sonsuz ve $\mathrm{N}>\mathrm{T}$ durumlarında Pesaran (2004) CD testi, $\mathrm{T}$ ya da N'in sonsuz olduğunda, $\mathrm{N}>\mathrm{T}$ ve $\mathrm{T}>\mathrm{N}$ durumlarının her ikisinde de yine Pesaran (2004) tarafından tekrar geliştirilen CD testi kullanılabilmektedir. Testlerin hipotezleri;

$H_{0}$ : Yatay kesit bağımlılı̆g yoktur,

$H_{1}$ : Yatay kesit bağımlılı̆̆ vardır şeklindedir.

Homojenlik testleri ise değişkenlere ait katsayıların homojen mi heterojen mi olduğunu göstermektedir. Yani yatay kesitlerin birinde meydana gelen bir değişimin, diğer ülkelerle aynı $\mathrm{m} 1$ yoksa farklı düzeylerde mi etkilendiğini test etmektedir. Ayrıca homojenlik testi sonucuna göre devam eden analiz sürecinde uygulanacak testlerin seçiminde belirleyici olmaktadır. Örneğin yatay kesit bağımlılık testleri değişkenlere uygulanacak birim kök testlerinin seçimi açısından önemli iken, değişkenlere ait katsayıların homojen olup olmadıkları da serilere uygulanacak eşbütünleşme testlerinin yorumlanması açısından önem arz etmektedir (Özcan ve Özmen, 2018: 7).

Çalışmada kullanacağımız homojenlik testi, Pesaran ve Yagamata (2008) tarafindan geliştirilen Delta $(\tilde{\Delta})$ testidir. Bu testte $Z^{c}$ büyük örneklemler için, $\bigotimes_{a d j}$ ise büyük örneklemler için önerilmektedir. Testin hipotezleri;

$H_{0}$ : Eğim katsayıları homojendir

$H_{1}$ : Eğim katsayıları heterojendir, şeklindedir.

Tablo 4'de her bir seri için CD test sonuçlarına yer verilmektedir.

Tablo 4: Yatay-Kesit Bağımlılığı Testleri (Değişkenler için)

\begin{tabular}{|c|c|c|c|c|c|c|c|c|c|c|}
\hline \multirow{2}{*}{$\begin{array}{l}\text { Sabitli } \\
\text { Model }\end{array}$} & \multicolumn{2}{|l|}{ lnkbg } & \multicolumn{2}{|l|}{ lnhdh } & \multicolumn{2}{|l|}{ lnpk } & \multicolumn{2}{|l|}{ lnhih } & \multicolumn{2}{|l|}{ lnenf } \\
\hline & İst. & Olas. & İst. & Olas. & İst. & Olas. & İst. & Olas. & İst. & Olas. \\
\hline $\begin{array}{l}C D_{l m} \\
(\mathrm{BP}, 1980)\end{array}$ & 39.947 & 0.000 & 31.630 & 0.007 & 22.361 & 0.099 & 42.195 & 0.000 & 30.099 & 0.012 \\
\hline $\begin{array}{l}C D_{l m} \\
\text { (Pesaran, } \\
2004)\end{array}$ & 4.555 & 0.000 & 3.036 & 0.001 & 1.344 & 0.089 & 4.965 & 0.000 & 2.757 & 0.003 \\
\hline $\begin{array}{l}C D \\
\text { (Pesaran, } \\
2004)\end{array}$ & -2.555 & 0.005 & -2.737 & 0.003 & -2.811 & 0.002 & -1.374 & 0.085 & -2.738 & 0.003 \\
\hline $\begin{array}{l}L M_{a d j} \\
\text { (PUY, } \\
2008)\end{array}$ & 21.709 & 0.000 & 9.740 & 0.000 & 14.114 & 0.000 & 3.432 & 0.000 & 4.026 & 0.000 \\
\hline
\end{tabular}

Tablo 4'e göre tüm değişkenlerin düzey değerleri için $H_{0}$ hipotezi güçlü bir şekilde (\%1 hata payı düzeyinde) $L M_{a d j}$ test sonuçlarına göre reddedilmektedir. Bu sonuçlar, paneli oluşturan ülkelere ait her bir seri ile diğer ülkeye ait seriler arasındaki bağımlılığı teyit etmektedir. Bu sonuçlar, 
tahmin edilecek regresyon modeli için yatay kesiti oluşturan ülkelere ait serilerin birbirlerinden etkilendiklerini göstermektedir.

Serilerin durağanlığını tespit etmek amacıyla birim kök testi yapılmıştır. Panel birim kök testleri, kesitler arasındaki bağımlılığın dikkate alınıp alınmamasına göre ikiye ayrılmaktadır. Birinci nesil panel birim kök testleri Hadri (2000), Breitung (2000), Choi (2001), Levin vd., (2002), Im vd., (2003) olarak adlandırılan testler, yatay kesit bağımlılığını dikkate almamaktadır. Yani seriler arasında yatay kesit bağımlılığı olmadığında birinci nesil testlerden yararlanılır. İkinci nesil panel birim kök testleri ise Bai ve Ng (2004; 2010); Pesaran (2007), Hadri ve Kurozumi (2012) kesitler arası ilişkiyi dikkate aldığı için daha güvenilir sonuçlar vermektedir. Yatay kesit bağımlılığ1 testi sonucunda, seriler arasında etkileşimin varlığı tespit edildiği için ikinci nesil panel birim kök testi uygulanmıştır. Hadri-Kuruzomi (2012) panel birim kök testi, Kwiatkowski, Phillips, Schmidt ve Shin (KPSS, 1992) testinin panel veri grupları için geliştirilmiş halidir. Bu testin boş ve alternatif hipotezi KPSS testinde olduğu gibi diğer birim kök testlerinin tersi şeklinde kurulmuştur. Bu test için iki tür test istatistiği hesaplanmıştır. Bunlar; $Z_{A}^{s p c}$ ve $Z_{A}^{l a}$, dir.

Hipotezler;

$H_{0}$ : Birim kök yoktur,

$H_{1}$ : Birim kök vardır, şeklindedir.

Modeldeki değişkenlere ait birim kök testi sonuçları Tablo 5' da verilmiştir. 
Tablo 6: Modelde Yatay-Kesit Bağımlılığg ve Homojenite Testleri

\begin{tabular}{|c|c|c|}
\hline $\begin{array}{l}\text { Regresyon Modeli: } \\
\ln k b g_{i t}=\beta_{0}+\beta_{1 i} \ln p k_{i t}+\beta_{2 i} \ln h d h_{i t}+\beta_{3 i} \ln h i h_{i t}+\beta_{4 i} \ln e n f_{i t}+\varepsilon_{i t}\end{array}$ & İst. & Olasilık \\
\hline \multicolumn{3}{|l|}{ Yatay kesit bağımlılık testleri } \\
\hline$L M(\mathrm{BP}, 1980)$ & $52.496^{* * *}$ & 0.000 \\
\hline$C D_{l m}$ (Pesaran, 2004) & $6.846^{* * *}$ & 0.000 \\
\hline$C D$ (Pesaran, 2004) & $5.434 * * *$ & 0.000 \\
\hline$L M_{a d j}(\mathrm{PUY}, 2008)$ & $2.402 * *$ & 0.008 \\
\hline \multicolumn{3}{|l|}{ Homojenite testleri: } \\
\hline 8( & $3.365 * * *$ & 0.000 \\
\hline $\mathbb{B}_{a d j}^{0}$ & $3.804 * * *$ & 0.000 \\
\hline
\end{tabular}

Not: $* * *, * *, *$ istatistiki olarak $\% 1, \% 5$ ve $\% 10$ anlam düzeyini göstermektedir.

Tablo 6'deki test sonuçlarına göre model için yapılacak testlerde "yatay kesit bağımlılığ1 yoktur" şeklindeki hipotez $L M_{a d j}$ test sonuçlarına göre reddedilmiş̧tir. Diğer yandan homojenlik testi sonuçlarına göre değişkenlere ait eğim katsayıları heterojendir. Aynı zamanda eşitlik 2 de yer verilen her bir değişken için $\mathrm{CD}$ test sonuçları regresyon modeli için gerçekleştirilen $\mathrm{CD}$ test sonuçlarını teyit etmektedir.

Serilerin uzun dönemde birlikte hareket edip etmediklerinin anlaşılması için yatay kesit bağımlılığını göz önünde bulunduran ve eğim katsayılarının heterojen olduğunu varsayan Westerlund ve Edgerton (2007) tarafından geliştirilen eş bütünleşme testi kullanılmıştır. Bu testin kritik değerleri bootstrap yaklaşımına dayanmaktadır. LM bootstrap testi, McCoskey ve Kao'nun geliştirmiş̧ olduğu Lagrange Çarpanı testine dayanmakta olup, yatay kesit bağımlılığının olması, durumunda LM testi bootstrap kritik değerler ile ekonometrik modellerde panelin geneli için eşbütünleşmenin olup olmadığını test etmektedir (Westerlund ve Edgerton, 2007:186-188)

Tablo 7: LM Bootstrap Eşbütünleşme Testi Sonuçları

\begin{tabular}{|c|c|c|c|c|c|c|}
\hline \multirow[b]{2}{*}{$\begin{array}{l}\text { LM bootstrap } \\
\text { (Ho: cointegration) }\end{array}$} & \multicolumn{3}{|c|}{ Sabitli } & \multicolumn{3}{|c|}{ Sabitli ve Trendli } \\
\hline & İstatistik & $\begin{array}{c}\text { Asimptotik } \\
\text { olasilık }\end{array}$ & $\begin{array}{c}\text { Bootstrap } \\
\text { olasilik }\end{array}$ & İstatistik & $\begin{array}{c}\text { Asimptotik } \\
\text { olasılık }\end{array}$ & $\begin{array}{c}\text { Bootstrap } \\
\text { olasılik }\end{array}$ \\
\hline$L M_{N}^{+}$ & $10.453 *$ & 0.002 & 0.000 & $6.053 *$ & 0.002 & 0.000 \\
\hline
\end{tabular}

Tablo 7'da Westerlund ve Edgerton (2007) eşbütünleşme testi sonucuna yer verilmiştir. Modelde yatay kesit bağımlılığı olduğu için Bootstrap olasılık değeri dikkate alınmıştır. Westerlund ve Edgerton (2007) Eşbütünleşme testi sonuçlarına göre "eşbütünleşme vardır" boş hipotezi \%1 anlamlılık düzeylerinde reddedilememektedir. lnkgb, lnhih, lnhdh, lnpk ve lnenf değişkenleri arasında eş bütünleşme ilişkisi olduğu bulgusu elde edilmiştir.

Bu çalışmada hisse senedi piyasası gelişimi ve ekonomik büyüme arasındaki uzun dönemli ilişkiyi tespit etmek amacıyla iki ayrı tahmin yöntemi kullanılmıştır. Bu yöntemler Ortak İlişkili Etkiler (Common Correlated Effects (CCE)) ve Genişletilmiş Ortalama Grup Tahmincisi (Augmented Mean Group (AMG)) yöntemleridir. 
Panel verili analizlerde birinci nesil tahmincilerden ortalama grup tahmincisi (Mean Group Estimator-MG) ile havuzlanmış ortalama grup tahmincisi (Pooled Mean Group Estimator-PMG) analizlerde heterojenliğe dirençli iken; yatay kesit bağımlılığına karş1 ise dirençli değildirler. Çalışmamızda yer alan yatay kesitler arasında bağımlılık tespit edilmesi nedeniyle; birinci nesil tahminciler yerine ikinci nesil tahmincilerden Ortak İlişkili Etkiler (Common Correlated EffectsCCE) ile Genişletilmiş Ortalama Grup Tahmincisi (Augmented Mean Group-AMG) yöntemleri kullanılmıştır.

Yatay kesitler arasındaki bağımlılı̆̆ dikkate alarak uzun dönemli ilişkileri analiz etme imkanı sunan Ortak İlișkili Etkiler (Common Correlated Effects-CCE) tahmincisi, "2005 Chudik ve Pesaran” ile 2006 yılında Pesaran'ın çalıșmalarıyla ortaya çıkmıștır (Kar ve BaysalKar, 2018: 2553). CCE tahmincisi; bağımsız değişkenler, dönem katsayı tahmincileri ve gözlenemeyen etkileri hem durağan hem de dışsal kabul eder iken; bunların birinci dereceden bütünleşik olmaları, durağan olmaları ve/veya eşbütünleşik olmaları halinde de tutarlıdır (Nazlığlu, 2010: 101; Özcan ve Özmen, 2018: 44).

Genişletilmiş Ortalama Grup (Augmented Mean Group-AMG) tahmincisi, Eberhardt ve Bond (2009), Eberhardt ve Teal (2011) ve Eberhardt (2012) geliştirilmiş olup; yatay kesitlerin katsayılarının ortalamalarının alınması yolu ile hesaplama yapmaktadır. AMG tahmincisi, panelin yatay kesit boyutunu oluşturan gruplar ile panelin tamamına dair eşbütünleşme katsayılarını hesaplayabilme imkanı sağlamaktadır. Bu tahminci, panel veri literatüründe yeni sayılabilecek bir tahminci olmakla birlikte; 2 temel özelliği bulunur: İlk olarak çalışmamızda seçilmesinin nedeni olan yatay kesitler arası bağımlılı̆̆ına direnç gösteren bir tahminci olmasıdır. Diğer özelliği ise panel kesitler arasındaki gözlemlenebilir ve gözlemlenemeyen faktörlerle birlikte, zaman serilerinin özelliklerine de duyarlı sonuçlar sağlamaktadır. Bir panel veri setinde, zaman boyutunun uzaması değişkenlerde durağan olmama sorununa yol açabilmektedir. Durağanlığı dikkate almayan tahmincilerle yapılan analiz sonuçlarında, hatalı sonuçlara ulaşma ya da sahte regresyonlar ortaya çıkarabilmektedir. Bu açıdan AMG tahmincisi durağan olmama halinde de etkin sonuçlar vermekte olan bir tahminci olup; ayrıca eşbütünleşme katsayılarının aritmetik ortalamasını ağırlıklandırarak tahmin etme özelliği sayesinde, farklı katsayı tahmincileri içerisinde oldukça güçlü sonuçlar sağlamaktadır (Özcan ve Özmen, 2018: 45; Eruygur ve Özokcu, 2016: 235)

Uzun dönemli ilişkilerin incelenmesinde kullanılan CCE ve AMG tahmincilerine dair çalışmamızda analiz edilen değişkenlerin tahmin sonuçları Tablo 8'de verilmiştir. 


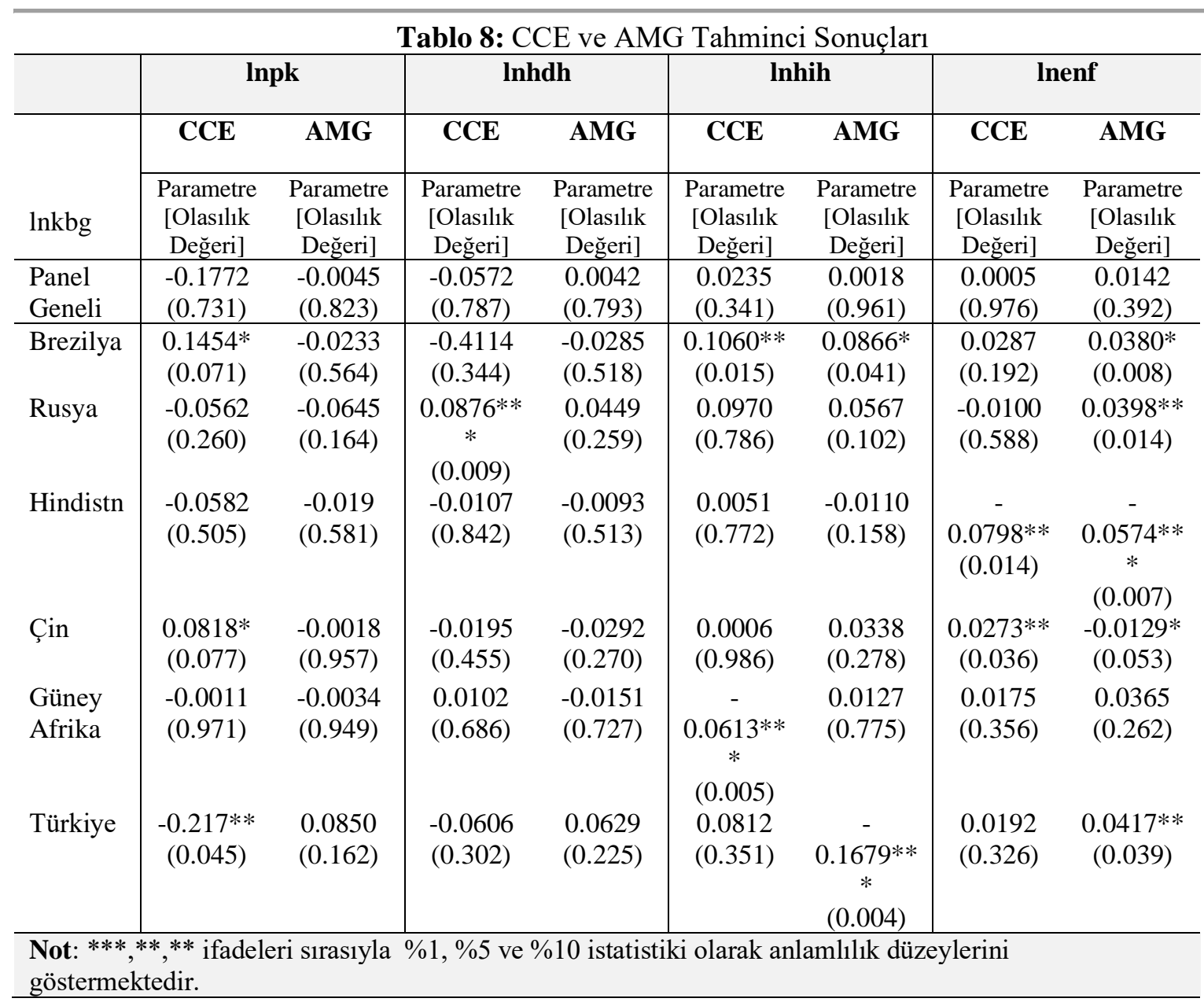

Tablo 8'de yer alan CCE ve AMG test sonuçları, hisse senedi piyasasının ekonomik büyüme (per capita) üzerindeki etkilerini göstermektedir. Analiz sonuçlarına göre; lnpk (hisse senedi piyasa kapitalizasyonu) Brezilya ve Çin'de ekonomik büyümeye pozitif etki gösterirken Türkiye'de bu etki negatif olarak görülmektedir. lnhdh (hisse senedi devir hızı) değişkeninin ekonomik büyümeye sadece Rusya'da etki ettiği ve etki yönününse pozitif olduğu sonucu görülmektedir. lnhih değişkeninin ise Brezilya, Güney Afrika ve Türkiye'de ekonomik büyümeyi etkilediği yönünde sonuçlar ortaya konulurken etki yönüne bakıldığındaysa; Brezilyada pozitif, Türkiye ve Güney Afrika'da negatif yönde etkilediği görülmektedir. Enflasyon, CCE ve AMG test sonuçlarında Brezilya, Rusya ve Türkiye'de pozitif etki yarattığı sonucu elde edilmiştir. Hindistan'da ise bu etkinin negatif olduğu görülmektedir.

CCE ve AMG testlerinin istatistiksel olarak anlamlı olan katsayıları yorumlandığında piyasa kapitalizasyonunda (lnpk) meydana gelen \%1'lik bir artış, kişi başı ekonomik büyüme üzerinde Brezilya'da yaklaşık olarak \%0.15, Çin'de $\% 0.08$ artışa sebep olmakta, ancak Türkiye'de ise $\% 0.21$ azalışa yol açmaktadır. Hisse senedi devir hızında meydana gelen \%1'lik bir artışın BRICS-T ülkeleri içerisinde sadece Rusya'da ekonomik büyüme ile ilişkili olduğu ve ekonomik büyümede \%0.08'lik bir artış yarattı̆̆ görülmektedir. Hisse senedi işlem hacminde ise Brezilya'da \%1 oranındaki bir artış, ekonomik büyümeyi $\% 0.10$ pozitif etkilerken, Türkiye $\% 0.16$ ve Güney Afrika'da \%0.06 azalttığ1 tespit edilmiştir. Son olarak enflasyon ile ekonomik büyüme ilişkisine bakıldığında ise; pozitif ilişki tespit edilen ülkeler Brezilya $\% 0.038$, Rusya $\% 0.039$ ve Türkiye $\% 0.04$ olduğu görülmektedir. Yani enflasyon Brezilyada \%1 arttığında ekonomik büyümeyi \%3 arttırmaktadır. Rusya ve Türkiye'de de yakın oranlarda enflasyon ekonomik büyüme ilişkisi görülmekte olup, pozitif ilişki gözlenmiştir. 
Hindistan ve Çin'de ise enflasyon oranındaki \%1'lik bir artış ekonomik büyümede sırasıyla \%0.05 ve $\% 0.01$ azalmaya neden olduğu tespit edilmiştir.

\section{Sonuç}

Bu çalışmada hisse senedi piyasası gelişimi ile ekonomik büyüme ilişkisi, BRICS-Türkiye örnekleminden yola çıkılarak incelenmektedir. İlgili literatürde yapılmış ilk çalışmalar olan; Bagehot (1873), Schumpeter (1912), Patrick (1966), McKinnon-Shaw (1973) çalışmalarından, günümüze dek uzanan birçok akademik çalışma ve bulgularının incelenmesi sonucu ele alınan değişkenler yardımıyla, hisse senedi piyasası ekonomik büyüme ilişkisi kısa ve uzun dönemde analiz edilmiştir. Ayrıca literatürde finansal piyasalar ile ekonomik büyüme ilişkisini inceleyen çalışmalar oldukça yoğun iken; finansal piyasaların bir alt alanı olan hisse senedi piyasaları ile ekonomik büyüme ilişkisini inceleyen çalışma nispeten daha azdır. Yapılmış çalışmalarda bu iki büyüklük arasındaki ilişkinin yönüne dair genel kabul görmüş bir teoriye ulaşılamamakla birlikte; genel eğilimin hisse senedi piyasası gelişiminden ekonomik büyümeye doğru pozitif ilişkinin varlığını göstermekte olup son birkaç yılda yapılan çeşitli analiz sonuçlarındaysa etki yönünün çift yönlü nedensellik barındırabildiği de görülebilmektedir.

Hisse senedi piyasası göstergesi olarak piyasa kapitalizasyonu, devir hızı ve işlem hacmi verilerini ile ayrıca enflasyonu da analize dahil ederek ekonomik büyüme ilişkisini inceleyen bu çalışma sonuçlarında; Westerlund ve Edgerton (2007) eşbütünleşme testi sonuçlarına göre lnkgb, lnhih, lnhdh, lnpk ve lnenf değişkenleri arasında uzun dönemli eş bütünleşme ilişkisi olduğu tespit edilmiștir. Yatay kesit bağımlılığını dikkate alarak uzun dönemli ilișkileri tahmin etmede kullanılan CCE ve AMG test sonuçlarında ise, hisse senedi piyasa kapitalizasyonu, Brezilya ve Çin'de ekonomik büyümeye pozitif etki gösterirken Türkiye'de bu etki yönü negatif olarak görülmektedir. Hisse senedi devir hızı değişkeninin ekonomik büyümeye sadece Rusya'da etki ettiği ve etki yönününse pozitif olduğu sonucu görülmektedir. lnhih değişkeninin Brezilya'da pozitif, Türkiye ve Güney Afrika'da negatif etkisi bulunmuştur. Enflasyon, CCE ve AMG test sonuçlarında Brezilya, Rusya ve Türkiye'de pozitif etki yarattığı sonucu elde edilmiş iken; günümüz dünyasında en hızlı gelişme gösteren ülkelerden olan Çin ve Hindistan'da ise bu etkinin yönü negatiftir. Bu sonuçlardan yola çıkılarak genel bir değerlendirme yapılacak olursak; gelişmiş ülke olarak kabul gören ülkelerde, hisse senedi piyasası ile ekonomik büyüme pozitif yönlü ilişki gösterirken, gelişmekte olan ülkelerin ise ekonomik büyümenin hisse senedi piyasası ile ilişkisiz veya negatif ilişkili olabileceği sonucuna ulaşılmıştır. Böyle bir etki yönü farklılığının ise gelişmiş ve gelişmekte olan ülkelerde genel ekonomik yapı ve finansal piyasalarındaki kırılganlıklar temel teşkil edebileceğini belirtmek mümkündür.

\section{Kaynakça}

Adjasi, C.K.D., \& Biekpe, N.B. (2006). Stock market development and economic growth: the case of selected African Countries. African Development Review, 18(1), 144-161. https://doi.org/10.1111/j.1467-8268.2006.00136.x

Akyol, H., \& Karakuş, K. (2019). Reel aktivite ve hisse senedi getirileri arasındaki ilişkinin teorik ve ampirik olarak incelenmesi. Uluslararası Sosyal Araştırmalar Dergisi, 12(67), 814-821. http://dx.doi.org/10.17719/jisr.2019.3768

Alawin, M., Ali, A.T., \& Merza, E. (2018). The relationship between economic growth and stock market. International Journal of Advances in Management and Economics, 7(5), 1-8.

Antonios, A. (2010). Stock market and economic growth: an empirical analysis for Germany. Business and Economics Journal, 2010(1), 1-12. https://doi.org/10.35808/ersj/296 
Arestis, P., Demetriades, P. O., \& Luintel, K.B. (2001). Financial development and economic growth: the role of stock markets. Journal of Money, Credit and Banking, 33(1), 16-41. https://doi.org/10.2307/2673870

Aslan, Ö., \& Küçükaksoy, İ. (2006). Finansal gelişme ve ekonomik büyüme ilişkisi: Türkiye ekonomisi üzerine ekonometrik bir uygulama. Ekonometri ve Istatistik Dergisi, 4(2006), 1228. https://doi.org/10.18070/erciyesiibd.523605

Atje, R., \& Jovanovic, B. (1993). Stock markets and development. European Economic Review, 37(2-3), 632-640. https://doi.org/10.1016/0014-2921(93)90053-d

Aydemir, O. (2008). Hisse senedi getirileri ve reel sektör arasındaki ilişki: ampirik bir çalışma. Afyon Kocatepe Üniversitesi IIBF Dergisi, 10(2), 37-55.

Azam, M., Haseeb, M., Samsi, A.B., \& Raji, J.O. (2016). Stock market development and economic growth: evidences from Asia-4 countries, International Journal of Economics and Financial Issues, 6(3), 1200-1208.

Bai, J., \& Ng, S. (2004). A panic attack on unit roots and cointegration. Econometrica, 72(4), 11271177. https://doi.org/10.1111/j.1468-0262.2004.00528.x

Bayar, Y., Kaya, A., \& Yıldırım, M. (2014). Effects of stock market development on economic growth: evidence from Turkey", International Journal of Financial Research, 5(1), 93-100. ISSN 1923-4023 E-ISSN 1923-4031, https://doi.org/10.5430/ijfr.v5n1p93

Beck, T., \& Levine, R. (2004). Stock markets, banks, and growth: panel evidence. Journal of Banking \& Finance, 28(2004), 423-442. https://doi.org/10.1016/s0378-4266(02)00408-9

Bencivenga, V.R., Smith, B.D., \& Starr, M.R. (1996). Equity markets, transactions costs and capital accumulation: an 1llustration, The World Bank Economic Review, 10(2), 241-265. https://doi.org/10.1093/wber/10.2.241

Boubakari, A., \& Jin, D. (2010). The role of stock market development in economic growth: evidence from some Euronext Countries. International Journal of Financial Research, 1(1), 14-20. https://doi.org/10.5430/ijfr.v1n1p14

Breitung, J. (2000). The local power of some unit root tests for panel data, in advances in econometrics, Vol. 15: Nonstationarity Panels, and Dynamic Panels, Baltagi, B.H. (ed.), 161177. https://doi.org/10.1016/s0731-9053(00)15006-6

Breusch, T.S., \& Pagan, A. (1980). The lagrange multiplier test and its applications to model specification in Econometrics. Review of Economic Studies, 47(1), 239-253. https://doi.org/10.2307/2297111

Chang, S.C. (2001). Stock market development and economic growth: A panel data approach. Asia Pacific Management Review, 6(3), 357-376.

Choi, I. (1993). Asymptotic normality of the least-squares estimates for higher order autoregressive integrated process with some applications. Econometric Theory, 9(2), 263-282. https://doi.org/10.1017/s0266466600007532

Çetenak, Ö., \& Haykır, Ö. (2019). Borsa likiditesi ile ekonomik büyüme arasındaki ilişki: Borsa İstanbul örneği. Kahramanmaraş Sütçü İmam Üniversitesi Sosyal Bilimler Dergisi, 16 (2), 576-591. https://doi.org/10.33437/ksusbd.552463

Eberhardt, M., \& Bond, S. (2009). Cross-section dependence in nonstationary panel models: a novel estimator. MPRA- Munich Personal RePEc Archive, 17692, 1-28. 
Eberhardt, M., \& Teal, F. (2011). Econometrics for grumblers: a new look at the literature on crosscountry growth empirics. Journal of Economc surveys, 25(1), 109-155. https://doi.org/10.1111/j.1467-6419.2010.00624.x

Eberhardt, M.(2012). Estimating panel time-series models with heterogeneous slopes. SAGE Journals, 12(1), 61-71, https://doi.org/10.1177/1536867X1201200105

Enisan, A.A., \& Olufisayo, A.O. (2009). Stock market development and economic growth: evidence from seven Sub-Sahara African Countries. Journal of Economics and Business, 61(2), 162171. https://doi.org/10.1016/j.jeconbus.2008.05.001

Eruygur, O., \& Özokcu, S. (2016). Türkiye'de iklim değişikliğinin buğday verimi üzerine etkileri: bir heterojen panel çalışması. Ekonomik Yaklaşım, 27(101), 219-255. https://doi.org/10.5455/ey.35944

Farmer, R. E. (2012). The stock market crash of 2008 caused the great recession: Theory and evidence. Journal of Economic Dynamics and Control, 36(5), 693-707. https://doi.org/10.1016/j.jedc.2012.02.003

Geyikçi, U. B. (2017). Türkiye'de hisse senedi piyasası ve ekonomik gelişme ilişkisinin ARDL sınır testi yaklaşımı ile analizi. İşletme Araştırmaları Dergisi, 9(3), 197-212. https://doi.org/10.20491/isarder.2017.295

Gilchrist, S., Yankov, V., \& Zakrajšek, E. (2009). Credit market shocks and economic fluctuations: evidence from corporate bond and stock markets. Natıonal Bureau Of Economic Research, Working Paper 14863. https://doi.org/10.3386/w14863

Goldsmith, R.W.(1959). Financial structure and development as a subject for international comparative study. NBER-National Bureau of Economic Research, 114 - 123. http://www.nber.org/chapters/c4417

Gökdeniz, İ., Erdoğan, M., \& Kalyüncü, K. (2003). Finansal piyasaların ekonomik büyümeye etkisi ve Türkiye örneği (1989-2002). G. Ü. Ticaret ve Turizm Eğitim Fakültesi Dergisi, 1, 107117. https://doi.org/10.24889/ifede.268176

Gözbaşı, O. (2015). Hisse senedi piyasası gelişimi ve ekonomik büyüme etkileşimi: gelişmekte olan ülkeler örneği. Eskişehir Osmangazi Üniversitesi İ̈BF Dergisi, 10(2), 269-284. https://doi.org/10.14780/muiibd.434958

Greenwood, J., \& Smith, B. (1997). Financial markets in development, and the development of financial markets, Journal of Economic Dynamics and Control, 21(1), 145-181. https://doi.org/10.1016/0165-1889(95)00928-0

Gurley, J.G., \& Shaw, E.S. (1955). Financial aspects of economic development. The American Economic Review, 45(4), 515-538. https://www.jstor.org/stable/1811632

Hadri, K. (2000). Testing for stationarity in heterogeneous panel data. The Econometrics Journal, 3(2), 148-161. https://doi.org/10.1111/1368-423x.00043

Hadri, K., \& Kurozumi, E. (2012). A simple panel stationarity test in the presence of serial correlation and a common factor. Economics Letter, 115, 31-34. https://doi.org/10.1016/j.econlet.2011.11.036

Harris, R.D.F. (1997). Stock markets and development: A re-assessment. European Economic Review, 41(1997), 139-146. https://doi.org/10.1016/s0014-2921(96)00021-9

Helhel, Y. (2019). Kırılgan Beşli ülkelerde hisse senedi piyasası gelişimi ve ekonomik büyüme ilişkisi. İşletme ve İktisat Çalışmaları Dergisi, 7(1), 19-29. https://doi.org/10.32479/iicd 
Ho, S.Y. (2018). Determinants of economic growth in Hong Kong: The role of stock market development. Cogent Economics \& Finance, 6(2018), 1510718. https://doi.org/10.1080/23322039.2018.1510718

Hoque, M.E., \& Yakob, N.A. (2017). Revisiting stock market development and economic growth nexus: The moderating role of foreign capital inflows and exchange rates. Cogent Economics \& Finance, 5(1), 1-17. https://doi.org/10.1080/23322039.2017.1329975

Im, K.S., Pesaran, M.H., \& Shin, Y. (2003). Testing for Unit Roots in Heterogeneous Panels. Journal of Econometrics, 115(1), 53-74. https://doi.org/10.1016/s0304-4076(03)00092-7

Ishioro, B.O. (2013). Stock Market Development And Economic Growth: Evidence From Zimbabwe. EKON. MISAO PRAKSA DBK. GOD XXII. 2(2013), 343-360.

Jahfer, A., \& Inoue, T. (2014). Stock market development and economic growth in Sri Lanka. International Journal Business and Emerging Markets, 6(3), 271-282. https://doi.org/10.1504/ijbem.2014.063888

Kar, M., \& Ağır, H. (2011). Menkul kıymetler piyasaları, finansal kalkınma ve ekonomik büyüme: Türkiye örneği. İstanbul Üniversitesi İktisat Fakültesi Mecmuast, 56(1), 13-46. https://doi.org/10.3848/iif.2002.190.0968.

Kar, M., \& Kar Baysal, B. (2018). Mobil arabağlantı ücret düzenlemelerinde su yatağı etkisi: Türkiye örneği. Socıal Sclences Studies Journal, 4(20): 2543-2557. https://doi.org/10.26449/sssj.659

Kırankabeş, M.C., \& Başarır, Ç. (2012). Stock market development and economic growth in developing countries: an empirical analysis for Turkey. International Research Journal of Finance and Economics, 87(2012), 134-146.

Kwiatkowski, D., Phillips, P.C.B., Schmidt, P., \& Shin, Y. (1992). Testing the null hypothesis of stationarity against the alternative of a unit root. Journal of Econometrics, 54(1992), 159178. https://doi.org/10.1016/0304-4076(92)90104-y

Lazarov, D. Miteva-Kacarski, E., \& Nikoloski, K. (2016). An empirical analysis of stock market development and economic growth: the case of Macedonia. South East European Journal of Economics and Business, 11(2), 71-81. https://doi.org/10.1515/jeb-2016-0012

Levin, A., Lin, C.F., \& Chu, C.S.J. (2002). Unit root tests in panel data: asymptotic and finite-sample properties. Journal of Econometrics, 108(1), 1-24. https://doi.org/10.1016/s03044076(01)00098-7

Levine, R. (1991). Stock markets, growth, and tax policy. Wiley Online Library, 46(4), 1445-1465. https://doi.org/10.1111/j.1540-6261.1991.tb04625.x

Levine, R., \& Zervos, S. (1996). Stock Market Development and Long-Run Growth. The World Bank Economic Review, 10(2), 323-339. https://doi.org/10.1093/wber/10.2.323

Levine, R., \& Zervos, S. (1998). Stock markets, banks and economic growth. American Economic Review, 88, 537-558.

Lewis, W.A. (1954). Economic development with unlimited supplies of labour. The Manchester School, 22, 139. https://doi.org/10.1111/j.1467-9957.1954.tb00021.x

Lucas, R.E. (1988). On the mechanics of economic development. Journal of Monetary Economics, 22(1), 3-42.

McKinnon, R. (1973). Money and capital in economic development, Washington DC: The Brookings Institution. 
Naceur, S.B., Ghazouani, S. (2007). Stock markets, banks, and economic growth: empirical evidence from the MENA region. Research in International Business and Finance, 21(2), 297-315. https://doi.org/10.1016/j.ribaf.2006.05.002

Næs, R., Skjeltorp, J., \& Ødegaard, B. (2011). Stock market liquidity and the business cycle. Journal of Finance, 66(1), 139-176. https://doi.org/10.1111/j.1540-6261.2010.01628.x

Nagaishi, M. (1999). Stock market development and economic growth: dubious relationship. Economic and Political Weekly, 34(29), 2004-2012.

Naik, P.K., \& Padhi, P. (2015). On the linkage between stock market development and economic growth in emerging market economies: dynamic panel evidence. Review of Accounting and Finance, 14(4),1-20. http://dx.doi.org/10.1108/RAF-09-2014-0105

Nazlıoğlu, Ş. (2010). Makro iktisat politikalarının tarım sektörü üzerindeki etkileri: gelişmiş ve gelişmekte olan ülkeler için bir karşılaştırması [Yayımlanmamış Doktora Tezi]. Erciyes Üniversitesi Sosyal Bilimler Enstitüsü.

Nieuwerburgh, S.V., Buelens, F., \& Cuyvers, L. (2006). Stock market development and economic growth in Belgium. Explorations in Economic History, 43(2006), 13-38. https://doi.org/10.1016/j.eeh.2005.06.002

Nowbutsing, B.M., \& Odit, M.P. (2009). Stock Market development and economic growth: the case of Mauritius. IBER-International Business \& Economics Research Journal, 8(2), 77-88. https://doi.org/10.19030/iber.v8i2.3104

Nyasha, S., \& Odhiambo, N.M. (2016). Banks, Stock market development and economic growth in Kenya: an empirical 1nvestigation. Journal of African Business, 18(1), 1-23. https://doi.org/10.1080/15228916.2016.1216232

Özcan, G., \& Özmen, İ. (2018). Küreselleşme yükselen ekonomilerde gelir dağılımını etkiler mi?. Kahramanmaraş Sütçü İmam Üniversitesi İktisadi ve İdari Bilimler Fakültesi Dergisi, 3552.

Pan, L., \& Mishra, V. (2017). Stock market development and economic growth: empirical evidence from China. Monash Business School ISSN 1441-5429

Patrick, H.T. (1966). Financial development and economic growth in underdeveloped countries. Economic Development and Cultural Change, 14, 174-189. https://doi.org/10.1086/450153

Pesaran, M.H. (2004). General diagnostic tests for cross section dependence in panels. Center for Economic Studies \& Ifo Institute for Economic Research CESifo Working Paper No:1229. http://ssrn.com/abstract=572504.

Pesaran, M.H. (2007). A simple unit root test in the presence of cross-section dependence. Journal of Applied Econometrics, 22(2), 265-312. https://doi.org/10.1002/jae.951

Pesaran, M.H., \& Yamagata, T. (2008). Testing slope homogeneity in large panels. Journal of Econometrics, 142(1), 50-93. https://doi.org/10.1016/j.jeconom.2007.05.010

Rioja, F., \& Valev, N. (2004). Finance and the sources of growth at various stages of economic development. Economic Inquiry, 42(1), 127-140. https://doi.org/10.1093/ei/cbh049

Shaw, E.S. (1973). Financial deepening in economic development. Oxford University Press.

Singh, A. (1997). Financial liberalisation, stockmarkets and economic development. The Economic Journal, 107(442), 771-782. https://doi.org/10.1111/j.1468-0297.1997.tb00042.x 
Stein, H. (2008). Beyond the World Bank Agenda: An Institutional Approach to Development, $\begin{array}{llll}\text { University of } & \text { Chicago }\end{array}$ https://doi.org/10.7208/chicago/9780226771656.001.0001

Stern, N. (1989). The economics of development: a survey. The Economic Journal, 99(397), 597685. https://doi.org/10.2307/2233764

Şahin, D., \& Durmuş, S. (2018). Türkiye'de ekonomik büyüme, ihracat ve hisse senedi fiyatları arasındaki nedensellik ilişkisinin analizi. AVRASYA Uluslararası Araştırmalar Dergisi, 6(15), 808-825. https://doi.org/10.33692/avrasyad.510242

Tekin, B., \& Yener, E. (2019). BRICS ve G7 ülkeleri ile Türkiye'de hisse senetleri piyasaları ve ekonomik büyüme arasındaki nedensellik ve eşbütünleşme ilişkilerinin karşılaştırmalı analizi. Ankara Hacl Bayram Veli Üniversitesi İ̈BF Dergisi, 20(3), 535-559. https://doi.org/10.26745/ahbvuibfd.560403

Tuncer, G.C., \& Alövsat, M. (1998). Stock markets and economıc growth: a causality test. Institute of Social Sciences of Istanbul Technical University, https://www.researchgate.net/publication/256068094

Westerlund, J., \& Edgerton, D. (2007). A panel bootstrap cointegration test. Economics Letters, 97(3),185-190. https://doi.org/10.1016/j.econlet.2007.03.003

Yayla, N., Ceylan, R., \& Çeviş, İ. (2017). Türkiye'de hisse senetleri piyasası ile ekonomik büyüme ilişkisine ARDL yaklaşım. Social Sciences, 12(4), 185-198. https://doi.org/10.12739/nwsa.2017.12.4.3c0165

Yücel, F. (2009). Temel Bileşenler Yöntemiyle Türk sermaye piysası gelişiminin ekonomik büyüme üzerine etkilerinin bir analizi. Sosyoekonomi Society, 2009(1). https://ideas.repec.org/s/sos/sosjrn.html">Sosyoekonomi Journal. 